\title{
The development of Innovation team leader leadership
}

\section{behavior scale}

\author{
Wu Qiang ${ }^{1}$,Wang Jigan,Fan Chuanhao,Gao Hong,Xu Lei and Xue Tingting \\ School of Business, Hohai University, Nanjing 210098, China
}

Key words: Innovation team; leader; leadership behavior; scale

\begin{abstract}
On the base of connotative definition and theoretical basis, the initial measurement project of develop Innovation team leader leadership behavior scale refer to scales of scholars both at home and abroad, use the combination of quantitative and qualitative methods to select measurement project. The project obtains a scale where evaluation results structural dimensions, reliability and validity are rational,and then develop measuring Innovation team leader leadership behavior scale. It includes innovative task-oriented, personnel relationship-oriented, participating in innovation and toxic/destructive leadership behavior four primary indicators and sticking to the target, target monitoring and so on twenty-five secondary indicators.
\end{abstract}

\section{The initial measurement project of innovation team leader leadership behavior scale}

The initial measurement project originates in connotative definition and theoretical basis of innovation team leader leadership behavior. The author holds that Innovation team leader leadership behavior scale needs the doing that can measure circumstance, organization, task,member and a series of factors leaders faced with in the process of leading/instructing innovation team ${ }^{1}$. It includes innovative task-oriented leadership behavior(LTA), personnel relationship-oriented leadership behavior(LRE), participating in innovation leadership behavior(LPA) and toxic/destructive leadership

\footnotetext{
${ }^{1}$ Corresponding author : fch@hhu.edu.cn
} 
behavior(LTO) four dimensions.

\subsection{Innovation team leader's innovative task-oriented leadership behavior(LTA)}

The measurement project of innovation team leader's innovative task-oriented leadership behavior(LTA) needs to measure the doings in favor of learning innovative task requires,operating procedures and relevant information. By referring scales of transactional leadership behavior, creating structure and cross-border communication, the author developed the LTA measurement project. Through the revise with members and experts in innovation team, author forms the initial measurement project of Innovation team leader's LTA, as shown in table 1.

Table 1. The initial measurement project table of Innovation team leader's LTA

\begin{tabular}{|c|c|c|}
\hline measure indicator & measurement project & encoding \\
\hline $\begin{array}{l}\text { sticking to the } \\
\text { target }\end{array}$ & $\begin{array}{l}\text { team leader helps the whole team to focus on goals without } \\
\text { deviation }\end{array}$ & Ita1 \\
\hline $\begin{array}{l}\text { explaining the } \\
\text { target }\end{array}$ & $\begin{array}{l}\text { team leader can clearly explain to the employees task/project } \\
\text { goals, responsibilities, etc. }\end{array}$ & lta2 \\
\hline target monitoring & Team leader can monitor the reaching process of team goals & lta3 \\
\hline Checking schedule & $\begin{array}{l}\text { Team leader checks schedule according to the plan, look to } \\
\text { whether according with the target }\end{array}$ & lta4 \\
\hline $\begin{array}{l}\text { Planning target } \\
\text { systematically }\end{array}$ & Team leader can plan how to finish task/project from the details & lta5 \\
\hline Target assessment & Team leader formulates strict target assessment system for team & lta6 \\
\hline $\begin{array}{l}\text { Correcting } \\
\text { members behavior }\end{array}$ & $\begin{array}{l}\text { Team leader can timely find and correct members' behaviors that } \\
\text { have nothing to do with target }\end{array}$ & lta7 \\
\hline $\begin{array}{l}\text { Clarifying work } \\
\text { standard }\end{array}$ & $\begin{array}{l}\text { Team leader put forward specific and feasible work standard to } \\
\text { team members }\end{array}$ & lta8 \\
\hline $\begin{array}{l}\text { Describing the } \\
\text { vision }\end{array}$ & $\begin{array}{l}\text { Team leader will describe the position and meaning of the } \\
\text { research direction in the field to team members }\end{array}$ & lta9 \\
\hline coordination work & $\begin{array}{c}\text { Team leader knows how to organize and coordinate work to } \\
\text { avoid delay, repetitive work and resources waste }\end{array}$ & lta10 \\
\hline $\begin{array}{l}\text { Clarifying } \\
\text { responsibility }\end{array}$ & Team leader clearly tells us work tasks and responsibilities & lta11 \\
\hline $\begin{array}{l}\text { Fighting for } \\
\text { resources }\end{array}$ & Team leader fought lots of resources for us & lta12 \\
\hline $\begin{array}{c}\text { Maintaining } \\
\text { external } \\
\text { relationships }\end{array}$ & $\begin{array}{l}\text { Team leader established a good interactive relationship with } \\
\text { external organization }\end{array}$ & lta13 \\
\hline measure indicator & measurement project & encoding \\
\hline
\end{tabular}




\begin{tabular}{|c|c|c|}
\hline Praise promptly & Team leader can affirm our work and performance promptly & lta14 \\
\hline Inspiring members & Team leader uses incentives to inspire members to work hard & lta15 \\
\hline $\begin{array}{c}\text { Fair evaluation } \\
\text { system } \\
\text { construction }\end{array}$ & $\begin{array}{c}\text { Team leader makes fair evaluation on members' performance } \\
\text { lta16 }\end{array}$ & lta17 \\
\hline $\begin{array}{c}\text { Work democracy } \\
\text { Controlling } \\
\text { schedule }\end{array}$ & $\begin{array}{c}\text { Team leader will propose modified methods and suggestions on } \\
\text { how to improve team performance }\end{array}$ & lta18 \\
\hline
\end{tabular}

\subsection{Innovation team leader's personnel relationship-oriented leadership behavior(LRE)}

The measurement project of innovation team leader's personnel relationship-oriented leadership behavior(LRE) needs to measure the doings in favor of behavioral interaction, cognitive structure and working attitude. By referring scales of transformational leadership behavior, understanding and authorization, the author developed the LRE measurement project. Through the revise with members and experts in innovation team, author forms the initial measurement project of Innovation team leader's LRE, as shown in table 2.

Table 2. The initial measurement project table of Innovation team leader's LRE

\begin{tabular}{|c|c|c|}
\hline $\begin{array}{c}\text { measure indicator } \\
\text { membership }\end{array}$ & $\begin{array}{c}\text { measurement project } \\
\text { members }\end{array}$ & lre1 \\
\hline Providing space & Team leader provides members with sufficient free space & lre2 \\
\hline Training staff & $\begin{array}{c}\text { Team leader provides members with opportunities for } \\
\text { development and displaying talent }\end{array}$ & lre3 \\
\hline $\begin{array}{c}\text { Trusting staff } \\
\text { difficult tasks }\end{array}$ & Team leader gives trust to members' ability of performing & lre4 \\
\hline $\begin{array}{c}\text { Interacting with } \\
\text { members }\end{array}$ & $\begin{array}{c}\text { When making decisions that have an impact on the members, the } \\
\text { team leader is able to talk to their members to learn about their } \\
\text { responses and suggestions }\end{array}$ & lre5 \\
\hline $\begin{array}{c}\text { caring about the } \\
\text { life of members }\end{array}$ & $\begin{array}{c}\text { Team leader cares about the life of members, then get along with } \\
\text { members }\end{array}$ & lre6 \\
\hline $\begin{array}{c}\text { Describing the } \\
\text { vision }\end{array}$ & Team leader describes a good prospect to members & lre7 \\
\hline $\begin{array}{c}\text { Encouraging } \\
\text { innovation }\end{array}$ & Team leader often encourages us to try new ways & lre8 \\
\hline $\begin{array}{c}\text { measure indicator } \\
\text { measurement project }\end{array}$ & encoding \\
\hline
\end{tabular}




\begin{tabular}{|c|c|c|}
\hline $\begin{array}{c}\text { creating innovative } \\
\text { atmosphere }\end{array}$ & Team leader often creates an atmosphere good for innovation & lre9 \\
\hline $\begin{array}{c}\text { Focusing on } \\
\text { emotional } \\
\text { communication }\end{array}$ & Team leader will find time to chat with team members & lre10 \\
\hline $\begin{array}{c}\text { Being welling to } \\
\text { listen to opinions }\end{array}$ & Team leader encourage members to express their ideas and & lre11 \\
\hline $\begin{array}{c}\text { Pay attention to } \\
\text { members' giving }\end{array}$ & Team leader focuses on the efforts of team members. & lre12 \\
\hline Close contact & Team leader maintain close contact with members & lre13 \\
\hline $\begin{array}{c}\text { Encouraging } \\
\text { cooperation }\end{array}$ & Team leader encourages cooperation among team members. & lre14 \\
\hline $\begin{array}{c}\text { Encouraging } \\
\text { member } \\
\text { development }\end{array}$ & Team leader gives advice to members,future career development & lre15 \\
\hline $\begin{array}{c}\text { Inspiring thinking } \\
\text { natrent }\end{array}$ & Team leader inspires members to analyze problems from & lre16 \\
\hline
\end{tabular}

\subsection{Innovation team leader's participating in innovation leadership behavior(LPA)}

The measurement project of innovation team leader's participating in innovation leadership behavior(LPA) needs to measure the doings in favor of enhancing the self-value and self-efficacy of members, participating in innovation process, team management and learning, giving the staff with good judgment, creativity, attention, influence, support, information and other resources and enhancing motivation level on the intrinsic motivation. By referring participatory leadership behavior scale, the author developed the LPA measurement project. Through the revise with members and experts in innovation team, author forms the initial measurement project of Innovation team leader's LPA, as shown in table 3.

Table 3. The initial measurement project table of Innovation team leader's LPA

\begin{tabular}{|c|c|c|}
\hline $\begin{array}{c}\text { measure indicator } \\
\text { making oneself an } \\
\text { example }\end{array}$ & $\begin{array}{c}\text { meam leader sets a good example with his/her performance in the } \\
\text { work }\end{array}$ & lpa1 \\
\hline Leading & $\begin{array}{c}\text { Team leader shows high requirements to work performance with } \\
\text { his/her own behaviors }\end{array}$ & lpa2 \\
\hline $\begin{array}{c}\text { Taking } \\
\text { responsibilities }\end{array}$ & $\begin{array}{c}\text { Team leader is responsible for the work and encourages to take } \\
\text { responsibilities }\end{array}$ & lpa3 \\
\hline measure indicator & measurement project & encoding \\
\hline
\end{tabular}




\begin{tabular}{|c|c|c|}
\hline $\begin{array}{l}\text { Encouraging } \\
\text { participation }\end{array}$ & $\begin{array}{l}\text { Team leader encourages members to participate in projects and } \\
\qquad \text { decision-making }\end{array}$ & lpa4 \\
\hline $\begin{array}{c}\text { Giving } \\
\text { opportunities }\end{array}$ & $\begin{array}{l}\text { Team leader always provide the members with sufficient free } \\
\text { space }\end{array}$ & lpa5 \\
\hline $\begin{array}{l}\text { Working together } \\
\text { to solve problems }\end{array}$ & $\begin{array}{l}\text { Team leader encourages members to work together to solve } \\
\text { problems }\end{array}$ & lpa6 \\
\hline $\begin{array}{l}\text { Exchanging } \\
\text { information with } \\
\text { each other }\end{array}$ & $\begin{array}{l}\text { Team leader encourages members to exchange information with } \\
\text { each other }\end{array}$ & lpa7 \\
\hline $\begin{array}{l}\text { Exchanging } \\
\text { different opinions }\end{array}$ & $\begin{array}{l}\text { Team leader encourages members to provide different opinions } \\
\text { on decision-making }\end{array}$ & lpa8 \\
\hline Working hard & Team leader works as hard as we do & lpa9 \\
\hline $\begin{array}{l}\text { Strong innovation } \\
\text { ability }\end{array}$ & Team leader has high quality and strong innovation ability & lpa10 \\
\hline
\end{tabular}

\subsection{Innovation team leader's toxic/destructive leadership behavior(LTO)}

The measurement project of innovation team leader's toxic/destructive leadership behavior(LTO) needs to measure the unfair and disreputable doings that have been continuously performed by leaders to violate legitimate benefits of organization and members. By referring scales of destructive leadership behavior, differential leadership behavior, toxic leadership behavior and abusive supervision, the author developed the LTO measurement project. Through the revise with members and experts in innovation team, author forms the initial measurement project of Innovation team leader's LTO, as shown in table 4.

Table 4. The initial measurement project table of Innovation team leader's LTO

\begin{tabular}{|c|c|c|}
\hline measure indicator & measurement project & encoding \\
\hline Differential leadership & $\begin{array}{c}\text { The team leader stresses group and affinities and care for people } \\
\text { having close relationship with him/her }\end{array}$ & lto1 \\
\hline arbitrariness & Team leader makes decisions on his/her own & lto2 \\
\hline partiality & Team leader often shows partiality to members he/she likes & lto3 \\
\hline partial tolerance & Team leader shows leniency to his/her close members & lto4 \\
\hline Partial control & $\begin{array}{c}\text { Team leader has less control over close members and let them } \\
\text { master core work }\end{array}$ & lto5 \\
\hline Partial promotion & $\begin{array}{c}\text { members close with team leader will receive more opportunities } \\
\text { for salary increase or welfare benefits than the average }\end{array}$ & lto6 \\
\hline award & measurement project & encoding \\
\hline
\end{tabular}




\begin{tabular}{|c|c|c|}
\hline Striking the opponents & $\begin{array}{c}\text { Letting the situation worse, team leader uses means to combat } \\
\text { the rival of his/her close members }\end{array}$ & lto7 \\
\hline non-action & Team leader ignores or promotes incompetent members & lto8 \\
\hline Suppressing criticism & Team leaders use threats and dictatorship to suppress criticism & lto9 \\
\hline $\begin{array}{c}\text { Making members } \\
\text { antagonistic to each } \\
\text { other }\end{array}$ & Team leader makes members antagonistic to each other & 1 1to10 \\
\hline
\end{tabular}

\section{Qualitatively developing the measurement project of innovation team leader leadership behavior}

In order to carry out a more thorough and detailed analysis of the applicability of the measurement project, the author invites nineteen experts(including three management professors, five associate professors of management, five doctoral candidates of management, three doctoral candidates in economics and thee doctors of engineering) to participate in the further screening of these projects ${ }^{2}$.

These experts independently carry on reading, analyzing and selecting according to their respective working background and research direction, their main works are as the following: (Giving suggestions on the appropriateness and accuracy of the item content, deleting projects that are not highly differentiated(lat4、1re8、lre14、lpa5、1pa7、1pa10), deleting projects that are ambiguous or vague(lta6、1ta18、1re4、1re11、1pa2、1to2、1to8), combining projects of similar content into a new project and coding(combining Ita7,Ita14 into Ita20; combining Ita10,Ita11 into Ita21; combining Ita3,Ita15 into Ita17; combining Ita6,Ita10,Ita13 into Ita18; combining Ita7,Ita9 into Ita19; combining Ita1,Ita3,Ita4,Ita5,Ita6 into Ita11) and increasing measurement projects of innovation team features; (Bying repeated communications, giving suggestions on the readability of the questionnaire, straightening out and determining the final statements ${ }^{3}$. After brainstorming discussion, repeated communications and agreements, ultimately forming a project pool with 32 items, as shown in table 5.

Table 5. The measurement project pool of innovation team leader leadership behavior

\begin{tabular}{|c|c|c|}
\hline number & measurement project & coding \\
\hline 1 & team leader helps the team to focus on goals without deviation & lta1 \\
\hline 2 & $\begin{array}{c}\text { team leader can clearly explain to the employees task/project } \\
\text { goals, responsibilities, etc. }\end{array}$ & lta2 \\
\hline 3 & Team leader can monitor the reaching process of team goals & lta3 \\
\hline 4 & Team leader can plan how to finish task/project from the details \\
\hline 5 & $\begin{array}{c}\text { Team leader put forward specific and feasible work standard to } \\
\text { team members } \\
\text { measurement project }\end{array}$ \\
\hline number & coding \\
\hline
\end{tabular}




\begin{tabular}{|c|c|c|}
\hline 6 & Team leader fought lots of resources for us & lta12 \\
\hline 7 & $\begin{array}{l}\text { Team leader established a good interactive relationship with } \\
\text { external organization }\end{array}$ & Ita13 \\
\hline 8 & Team leader uses incentives to inspire members to work hard & lta15 \\
\hline 9 & Team leader makes fair evaluation on members' performance & lta16 \\
\hline 10 & Team leader will tell members the rules and expectations & lta17 \\
\hline 11 & Team leader knows work schedule clearly & lta19 \\
\hline 12 & $\begin{array}{l}\text { Team leader can timely praise members and correct members' } \\
\text { behaviors that have nothing to do with target }\end{array}$ & 1 ta 20 \\
\hline 13 & $\begin{array}{l}\text { Team leader confirm task and responsibility to avoid delay, } \\
\text { repetitive work and resources waste }\end{array}$ & $1 \operatorname{ta} 21$ \\
\hline 14 & $\begin{array}{l}\text { Team leader helps to establish a good relationship between team } \\
\text { members }\end{array}$ & lre1 \\
\hline 15 & Team leader provides members with sufficient free space & lre2 \\
\hline 16 & $\begin{array}{l}\text { When making decisions that have an impact on the members, the } \\
\text { team leader is able to talk to their members to learn about their } \\
\text { responses and suggestions }\end{array}$ & lre5 \\
\hline 17 & $\begin{array}{l}\text { Team leader often creates an atmosphere that is good for } \\
\text { innovation }\end{array}$ & lre9 \\
\hline 18 & Team leader focuses on the efforts of team members & lre12 \\
\hline 19 & $\begin{array}{c}\text { Team leader inspires members to analyze problems from different } \\
\text { perspectives }\end{array}$ & lre16 \\
\hline 20 & $\begin{array}{l}\text { Team leader provides members with opportunities for } \\
\text { development and displaying talent }\end{array}$ & lre17 \\
\hline 21 & $\begin{array}{l}\text { Team leader cares about the life of members and maintain close } \\
\text { contact with members }\end{array}$ & lre18 \\
\hline 22 & $\begin{array}{l}\text { Team leader will describe the position and meaning of the } \\
\text { research direction in the field to team members }\end{array}$ & lre19 \\
\hline 23 & $\begin{array}{c}\text { Team leader sets a good example with his/her performance in the } \\
\text { work }\end{array}$ & lpa1 \\
\hline 24 & $\begin{array}{l}\text { Team leader is responsible for the work and encourages to take } \\
\text { responsibilities }\end{array}$ & lpa3 \\
\hline 25 & $\begin{array}{l}\text { Team leader encourages members to participate in projects and } \\
\text { decision-making }\end{array}$ & lpa4 \\
\hline 26 & $\begin{array}{l}\text { Team leader encourages members to work together to solve } \\
\text { problems }\end{array}$ & lpa6 \\
\hline number & measurement project & coding \\
\hline
\end{tabular}




\begin{tabular}{|c|c|c|}
\hline 27 & $\begin{array}{c}\text { Team leader encourages members to provide different opinions on } \\
\text { decision-making }\end{array}$ & lpa8 \\
\hline 28 & Team leader works as hard as we do & lpa9 \\
\hline 29 & $\begin{array}{c}\text { Letting the situation worse, team leader uses means to combat the } \\
\text { rival of his/her close members }\end{array}$ \\
\hline 30 & Team leaders use threats and dictatorship to suppress criticism & lto9 \\
\hline 31 & Team leader makes members antagonistic to each other & lto10 \\
\hline 32 & $\begin{array}{r}\text { The team leader stresses group and affinities and care for people } \\
\text { having close relationship with him/her }\end{array}$ \\
\hline
\end{tabular}

\section{Quantificationally developing the measurement project of innovation team leader leadership behavior}

Using a quantitative method to delete the unessential items, then forming the final scale. The paper follows the principles of great importance, strong sensitivity, good representation, strong independence and good distinction, considering items acceptable ${ }^{4}$. Through the questionnaire and using factor analyzing to the data collected, the paper selects the measurement project of innovation team leader leadership behavior.

\subsection{Questionnaire and data analysis}

From September 2011 to March 2012, using the innovation team funded by Ministry of Education as a research object,author in all issued 500 questionnaires and acquired 465 questionnaires, eliminating 84 invalid questionnaires, getting 381 valid questionnaires.

In addition to the personnel basic information of the sample and the basic information of the innovation team are designed in choice question, the other options are designed by Li Kete 7 scale, and the measure item comes from the item pool in Table 5.

Discrete degree method select measurement project from the perspective of the sensitivity. The study judges by using variation coefficient method, then deletes projects with a variation coefficient less than 0.35: 1ta15, lta19, lre9. Discrimination analysis method selects measurement project from the point of discrimination and importance ${ }^{5}$. Using $\mathrm{T}$ test to measure all projects. If the t-test results reach a significant level, then the project has the ability to identify samples with different degree of reaction, being discriminable; if not, it will be deleted. So under the standard, deleting projects: 1ta2, lta8, 1 ta15.

Furthermore, through the SPSS analysis, we can know that the internal consistency coefficient is 0.832 , greater than 0.8 . It shows that the questionnaire has a good reliability and measurement result, and is suitable for statistical analysis. At the same time, the KMO sample measure is 0.922, which means the questionnaire is suitable for exploratory factor analysis. Significant probability of Bartlett spherical test is 0.00 , which means the questionnaire has a strong correlation and is suitable for the 
factor analysis. This study uses principal component analysis to extract the factor, when selecting measurement project, referring Hair standard, chooses 0.5 as the critical point of the factor loading and deletes projects that do not meet the conditions. Then deleting projects:lta13, 1re12. From the variance decomposition principal component extraction, we can find that the cumulative contribution rate from the first four factors has been $84.324 \%$, and the variance contribution rate of factor 1 is relatively high, reaching $27.769 \%$. Therefore, the result of extracting variance accumulation contribution rate of four factors is more ideal ${ }^{6}$.

From the results of the variance accumulation contribution rate and the rotational component matrix, the measurement projects including the innovation team leader's innovative task-oriented leadership behavior factors we selected are as the following: LTA1, LTA2, LTA3, LTA4, LTA5, LTA6, LTA7, LTA8. The measurement projects including the innovation team leader's personnel relationship-oriented leadership behavior factors are as the following: LRE1, LRE2, LRE3, LRE4, LRE5, LRE6, LRE7. The measurement projects including the innovation team leader's participating in innovation leadership behavior factors we selected are as the following: LPA1, LPA2, LPA3, LPA4, LPA5, LPA6. The measurement projects including the innovation team leader's toxic/destructive leadership behavior factors we selected are as the following: LTO1, LTO2, LTO3, LTO4.

By using Maximum likelihood method to do the parameter estimation in AMOS statistical software, it turns out that the fitting results of four dimensional hypothesis model of Innovation team leader 4L leadership behavior measurement are ideal. The fitting results of each index are shown in Table 6, where $\mathrm{x}^{2} / d f$ is 2.846, RMSEA is 0.070, NFI is 0.937, TLI is 0.954, CFI is 0.958 .

Table 6. Innovative team leader $4 L$ leadership behavior measurement's four dimensional hypothesis model fitting index table

\begin{tabular}{|c|c|c|c|c|c|c|c|}
\hline \multirow{2}{*}{ Fitting index } & \multicolumn{4}{|c|}{ Absolute fitting index } & \multicolumn{3}{c|}{ Relative fitting index } \\
\cline { 2 - 8 } & $X^{2}$ & $d f$ & $\mathrm{x}^{2} / d f$ & RMSEA & NFI & TLI & CFI \\
\hline Fitting result & 771.387 & 271 & 2.846 & 0.070 & 0.937 & 0.954 & 0.958 \\
\hline
\end{tabular}

The C.R. value of each measurement index is greater than 1.96, passing the significance test, and the loading factor is greater than 0.5 .

\subsection{Evaluation on Innovation team leader leadership behavior scale ${ }^{7}$}

\subsubsection{Structural dimension evaluation}

We can know from Table 6, $\mathrm{x}^{2} / d f$, RMSEA, NFI, TLI and CFI of Innovation team leader leadership behavior scale's fitting model are ideal. So, we can consider that innovation team leader leadership behavior can be measured by innovative task-oriented leadership behavior, personnel relationship-oriented leadership behavior, participating in innovation leadership behavior and 
toxic/destructive leadership behavior. At the same time, the standardized factor load of the 25 measure items in 4 dimensions is greater than 0.71 , which indicates that the interpretation ability of each latent variable corresponds to the project is relatively strong.

\subsubsection{Reliability evaluation}

Construct reliability measures the scale's internal consistency, shown through Chronbach's $\alpha$ coefficient in confirmatory factor analysis. The whole reliability of Innovation team leader leadership behavior scale is 0.838 , greater than 0.80 , and the reliability coefficients of the 4 factors' each component table are all greater than 0.90 .

\subsubsection{Validity evaluation}

innovation team leader leadership behavior questionnaire is carried out by literature research, investigation and discussion. In order to make contents of the questionnaire more complete and clear, after the first draft of the questionnaire was completed, experts carried on qualitative analysis on title and expression and used quantitative analysis methods to delete the wrong measurement projects ${ }^{8}$. The selection of the sample is based on the innovative team funded by the Ministry of education. So judged from the rationality of the project, content validity of Innovation team leader leadership behavior scale is suitable.

\section{Formation of Innovation team leader leadership behavior scale}

According to the scale that pass tests of structure dimension, reliability and validity, building the index system of Innovation team leader leadership behavior scale, as shown in figure 1.

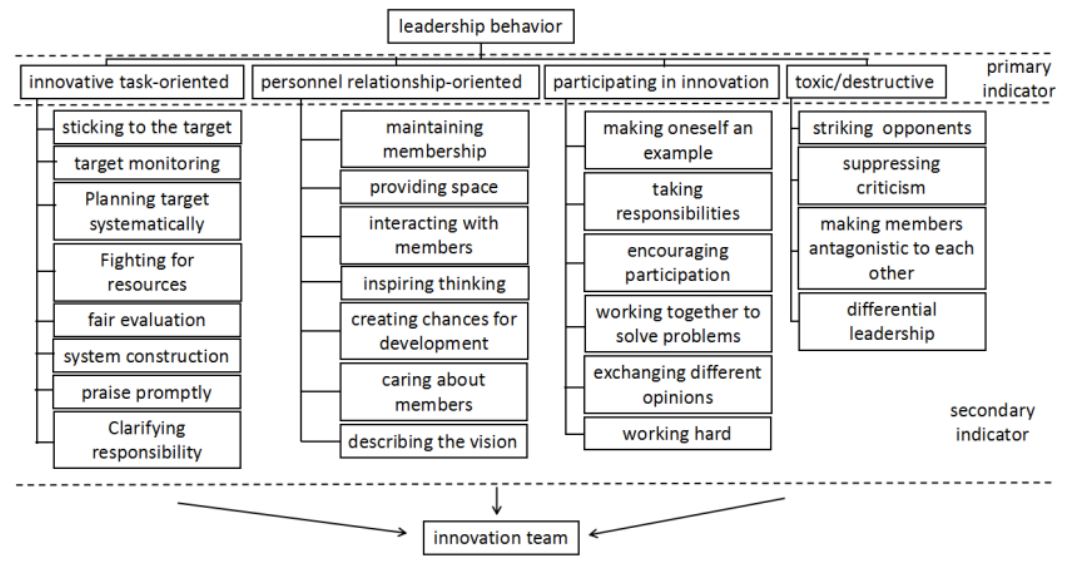

Figure 1. The index system of Innovation team leader leadership behavior scale

The index system of Innovation team leader leadership behavior scale includes innovative 
task-oriented, personnel relationship-oriented, participating in innovation and toxic/destructive leadership behavior four primary indicators and sticking to the target, target monitoring and so on twenty-five secondary indicators.

\section{Reference}

1. J. R. Hackman, Leading teams: Setting the stage for great performance[M]. Harvard Business School Press, 2002.

2. Zhou Ruichao .The essential qualities and training of scientific and technological innovation team leader[J]. Journal of Guangxi University(Philosophy and Social Science).2012, 34(2):93-96.

3. Huang Guo, Huang Jianan, Geng Wei. Research of Science and technology innovation team leader leadership quality model [J]. Management of Agriculture Science and Technology. 2015(01):90-91.

4. Zaccaro S J,Rittman A L,Marks M A.Team leadership. The Leadership Quarterly . 2001

5. Yan Shi . The reliability and validity of test of <Coach VICTORY leadership behavior scale> based on the structural equation model[J]. Journal of Guangzhou Sport University, 2014, 34(6):45-49.

6. DeShon, R.P., Kozlowski, S.W., Schmidt, A.M., Milner, K. R., Wiechmann, D., A multiple goal, multilevel model of feedback effects on the regulation of individual and team Performance in training [J]. Journal of Applied Psychology, 2004, 89(6):1035-1056.

7. Fan Chuanhao, Wang Jigan . Study on relationship between the entrepreneurial team heterogeneity and the team effectiveness[J]. Science Research Managemen,2013,08:35-41.

8. Liu Wen. Research on the influencing factors of Chinese government's leadership behavior[J]. Journal of Shanxi Finance and Economics University, 2010(S1):271-272. 